Abstract: The recent explosion of interest in black speculative fiction necessitates study of these new, innovative texts. Afro-Surrealism - a form of black

speculative fiction that began in the 1920s, gained popularity in the 1960s, and has now entered a third wave - closely mirrors its aesthetic cousin Afro-Futurism in its incorporation of

technology into

various texts. Both

Afro-Surrealism and

Afro-Futurism have sparked an

outpouring of visual

art, music, books, websites, and films, but these movements have more importantly reinvigorated the novel by integrating filmic storytelling techniques (e.g. jump cuts, montages). These narrative changes, coupled with frequent references to film, reveal how some black writers are rethinking technology. For the Afro-Surrealist, borrowing from film's visual technologies allows for a more meaningful retelling of history, while, for the Afro-Futurist, Afro-Surreal and Afrofuturistic Cinematic

\title{
Storytelling in Junot
} Diaz's The Brief Wondrous Life of Oscar

\section{Wao and Colson Whitehead's Zone}

cinematic writing represents people of colour's ability to work as technological innovators and creators. This paper positions Junot Díaz's The Brief Wondrous Life of Oscar Wao as the representative third-wave Afro-Surrealist text and Colson Whitehead's Zone One as the representative Afro-Futurist text. 
[F]ilmmaking walks a line between fiction and nonfiction that I think of as Afrosurrealist. When experimental films are doing their most exciting work they are delving into an interior, they are introspective and they explore the past an as imaginary.

- Terri Francis, from the Black Film Center Archives

Afro-Surrealism scholar Terri Francis once described Afro-Surreal films as inhabiting a landscape midway between the realistic and fantastic, and we can think of the Afro-Surreal novel as sharing similar characteristics. Afro-Surreal Expressionism, Amiri Baraka's term for the work of Henry Dumas and other writers whose strange or surreal work still manages to be "organically connected to this one" (164), teeters on the edge of folklore, myth, fable, history and science, bridging all through humor, a dreamlike narrative, and an uncertain optimism about the future. Similarly, Afrofuturism, a term coined by Mark Dery in 1994 to describe black fantastic art, also functions as a mode of black speculative fiction; still, when compared to Afro-Surrealism, Afrofuturism is more technology--focused and pessimistic about the future. In other words, while Afro-Surrealism references contemporary technologies and suggests these technologies (film, the Internet) offer opportunities for fighting oppression, Afrofuturism offers cautionary tales about black people's access to futuristic technologies and power.

Afrofuturist scholar Ytasha Womack reminds us that there is overlap between the two modes: "many artists," Womack reveals, "who create [Afro-Surreal] writing and art are also Afrofuturists" (170). But because both Afro-Surreal and Afrofuturist novels rely 
upon a film language that enhances the strangeness of the narrative - these novels' film allusions serve as reminders that we, as readers, have entered a foreign and unfamiliar world - the question remains: why separate such similar modes? Afro-Surrealism and Afrofuturism both offer strategies for understanding racial oppression, yet the two movements provide different methodologies for gaining power and agency. Analyzing these two movements' differences and similarities - particularly their use of cinematic storytelling techniques - thus allows for more nuanced conversations about oppressed people's relationships with power, labour, and technology.

Junot Díaz's The Brief Wondrous Life of Oscar Wao (2007) epitomizes the Afro-Surreal novel and the way in which Afro-Surrealism's cinematic qualities can reimagine historical traumas. Oscar Wao references history and folklore (with allusions to age-old curses and the myth of el coco, the boogeyman of Spanish folklore), our modern fables (Marvel comic books, The Lord of the Rings, Dune, Clay's Ark, and several other iconic narratives), science (through the characters' interest in medicine, the solar system, Newtonian physics, and the universe), and history (by citing John F. Kennedy, the Vietnam War, and, most prevalently, the Haitian genocide during the reign of Dominican dictator Rafael Trujillo). In contrast, while Colson Whitehead's Zone One (2011) weaves cinematic references throughout the story, the novel's futuristic focus and advanced technologies mark Whitehead's storytelling as Afrofuturistic, as opposed to Afro-Surreal. 


\section{Literary critic Tzvetan Todorov argues that hesitation,} particularly the reader's uncertainty whether events are real or imaginary, marks a text as 'fantastic' (20-26). Similarly, science fiction scholar Isiah Lavender's definition of science fiction draws inspiration from Darko Suvin's belief that science fiction is the "literature of cognitive estrangement" (qtd. in Lavender 28), and Lavender maintains that estrangement - a reader's sense of a story's weirdness or difference - is part of all speculative fiction, including fairy tales, folklore, and horror (29). Still, he views the cognitive element - a narrative's underlying logic - as unique to science fiction (29). For Lavender, science fiction is "weird fiction" that argues for a rational explanation (advanced technology, a futuristic setting) for an unusual event, as opposed to fairy tales and fables, which focus on magic or offer no logical explanation at all. Taken together, Todorov's and Lavender's definitions reveal that, while all speculative fiction is strange or weird, speculative fiction's subgenres vary to the degree that the narrative's structure renders unusual events as plausible or true.

Todorov also argues language's suggestive qualities help create the fantastic effect: a writer can create doubt about whether an event has occurred simply by selecting a specific verb (a verb's tense can make it unclear if an event occurs in a distant or ongoing past). To intensify the novel's sense of displacement, Díaz mingles past, present, and imperfect verb tenses, along with Spanish and English, and formal language with dialect. Díaz's characters are themselves immigrants (or children of immigrants), located in an unfamiliar and 
unsettling world, and Oscar Wao is firmly lodged neither in reality nor in make-believe. But what Todorov terms 'fantastic,' literary scholars may also describe as surreal; surreal literature hesitates between reality and fantasy and, in doing so, draws attention to the absurdity of 'real life.' As readers, we are never certain whether Oscar, the novel's socially awkward protagonist, is a victim of his own low selfesteem, nerdiness, and cultural alienation or if stranger phenomena (karma, bad luck) are responsible for his misfortune. This kind of layering marks Díaz's text as surreal, as both beautiful and marvelous, but it is Oscar Wao's vast historical framework that defines the novel as Afro-Surreal.

Writers of contemporary Afro-Surrealism encounter a challenge whenever they write about oppression: how can modern writers explore historical events, particularly traumatic ones, in ways that engage contemporary readers? How do these writers make history real and significant for readers who are distracted by Facebook, Twitter, Instagram, and daily text messages, and how do they do so without glossing over the depth or impact of our collective traumas? Revisiting trauma is never an enjoyable experience, but for writers who view understanding and revisiting history as essential to building a more just world, exploring the past seems essential. Yet these writers recognize that they need new tools in order to retell familiar stories. Contemporary Afro-Surreal narratives incorporate cinematic storytelling techniques into their narratives, first, as a means of making history relevant and, second, to suggest an African notion of 
temporality, one that merges past, present, and future imaginings of events.

Cinema, the dominant art form of the twentieth and twenty-first centuries, has become a recursive genre. Filmmaker Agnès Varda once described her films as cinécriture and argued that they were texts to be read (Reynaud). Today's Afro-Surreal novelists, on the other hand, create near-visual texts, and multiple allusions to various films and filmmaking techniques allow the reader to experience these novels as films. Furthermore, while much is made of Díaz's use of language, he realizes his vision, in part, through multiple cinematic references. In Oscar Wao, film references run rampant through the novel: from the references to sci-fi and fantasy films (Star Wars, Spiderman, The Matrix, The Dark Knight Returns), to a minor character's occupation (Oscar's sister's boyfriend works at a movie theatre), to Oscar Wao's own name (his first is a nickname for the film community's highest honour, the Academy Award; his surname alludes to an anime website). Although Díaz's film references may enchant contemporary readers - particularly his cinematic exploration of the Trujillo regime (the 'Failed Cattle Thief') - they fulfill a deeper purpose: they allow us to gain a new and more meaningful appreciation of the past.

Oscar Wao is who he is because of his upbringing. Hypatía Belicia Cabral, informally known as Beli, is a no-nonsense mother, who treats her son and daughter with little affection; and it is through a series of flashbacks that we start to understand why. Díaz's argument seems to be that brutal environments strangle love and 
make it nearly impossible to flourish. Through Beli's personal story, we learn how Trujillo's violence transformed a dreamy and romantic woman into a bitter mother who seems to do nothing but "scream and hit" (Díaz 54). Díaz uses cinematic techniques to tell this story: the narrative cuts back and forth from a distant past to a more recent one, and, throughout these pages, Díaz scatters subtle references to stock characters and the film community. The cinematic nature of this part of the novel, in particular, gives the past an immediacy and presence it may have lacked had it been told in another way.

Beli meets the love of her life in a club called El Hollywood, "a favorite hangout of Trujillo's" (Díaz 114). The club's name adds to the cinematic feel, as does Díaz's refusal to tell his readers Beli's lover's name. Known only as the Gangster, Beli's lover recalls a stock film character. He is tough, sexy, and, as one of Trujillo's agents, brutal. As readers, we get an idea of the Gangster's rough glamour; we see, as a montage, how he courts Beli:

He escorted her to the most exclusive restaurants of the capital, took her to the clubs that had never tolerated a nonmusician prieto . . . Treated her to plays, movies, dances, bought her wardrobes of clothes and pirate chests of jewelry, introduced her to famous celebrities, and once even to Ramfis Trujillo himself. (Díaz 124)

While we are provided with a glimpse of the Gangster's seductive side, we also learn he is "conflicted about his past deeds" (125) and that he and Beli's shared desire "to be free" (134) is never really possible. The scenes that reveal what happens to Beli once she 
becomes pregnant with the Gangster's child are told in a series of cinematic jump cuts, the quick series of violent images demonstrating the harshness of life during and after Trujillo's reign. These jump cuts are titled "Revelation," "Upon Further Reflection," "Name Game," and "Truth and Consequences," with the two shortest, "Upon Further Reflection" and "Truth and Consequences," containing exactly the same number of words (fifty--three). These scenes' parallelism forces comparison. Though we are unsure of the exact year, it is clear that "Upon Further Reflection" takes place in a more recent past (Beli is an older woman living in New York and reflecting on her life in Santo Domingo) than the scenes that follow it. "Name Game" takes place while Beli is still living in Santo Domingo, and "Truth and Consequences" occurs during an even earlier moment in time - we learn that the Gangster is further entrenched with Trujillo than we thought: he has married Trujillo's daughter. In this sequence of images, the reader's sense of time is manipulated: we read scenes from the distant past before reading about more recent events. Our sense of temporality disrupted, we are able to make connections only through visual images that emphasize pain, coldness, and brutality. In "Name Game," when Beli and the Gangster are in bed in a "love motel," the air above them is sliced by "blades pursued by a halfdozen flies"; in the later scene, "Upon Reflection," we see Beli "freezing in basement apartments in the Bronx and working her fingers to the bone" (Díaz 137). The jump cuts thus reveal Oscar Wao's message: life cannot be created or sustained in environments of such deep-seated cruelty. It is only through the narrator, Oscar 
Wao, and his optimism and willingness to ignore the Beli--initiated family curse and have his heart broken repeatedly that the other characters are able to behave more lovingly towards each other.

Of the two, Afrofuturism and Afro-Surrealism, Afrofuturism is the better known cultural movement. In the last ten years, Afrofuturism has blossomed into an aesthetic that responds to both mainstream science fiction and subsets of black speculative fiction through its earnestly edited Wikipedia entry, a show at the Studio Museum of Harlem ("The Shadows Took Shape"), an Afrofuturist group at the Schomburg Museum, themed books such as Ytasha Womack's AfroFuturism and Jalada Africa's Afrofuture(s), and recordings by pop star Janelle Monae. Cultural studies scholar Mark Dery argues that these kinds of Afrofuturist texts, rather than regarding blacks as a people in opposition to progress, position black people at the heart of technology-centered conversations (Dery 180). This knowledge - the idea that, historically, new technologies have often been used to demean and harm people of colour (eugenics, the Tuskegee experiment, the cells of Henrietta Lacks) - underlies Afrofuturism's dystopian landscape. Afrofuturism suggests that the past will repeat itself unless black people gain some control over futuristic technologies, and, consequently, Afrofuturist texts feature black protagonists wielding power through advanced technologies. In other words, the Afrofuturist text "aim[s] to reintegrate people of color into the discussion of cyberculture, modern science, technology, and sci-fi pop culture" (Womack 17). Afrofuturism, then, like Afro-Surrealism, relies upon the fantastic in order to better understand racial 
oppression. Afro-Surrealism, however, attempts to reconcile the past with the present, while Afrofuturism explores the importance of black creators of futuristic technologies.

Colson Whitehead infuses Zone One, his zombie apocalypse novel, with cinematic references. Yet the science underlying his project is what distinguishes it from the Afro-Surreal (such as Whitehead's John Henry Days). Zora Neale Hurston's anthropological work suggests that zombies have at least a somewhat scientific or psychological basis ${ }^{1}$, and so Whitehead's zombie plague, while not exactly realistic, is not altogether implausible either. Still, some readers may consider Zone One to fall under the category of Afro-Surrealism; however, the novel's dry, ironic humor and undercurrent of pessimism mixed with absurdity positions it as Afrofuturist (the Afro-Surrealist is always hopeful). Afrofuturism, which draws its philosophy from Futurism, cannot help but to have developed a somewhat skeptical outlook. While some scholars have argued that Futurism wouldn't have been possible without the trauma of World War I, Afrofuturist scholar Kodwo Eshun argues that another form of trauma - the trauma of eighteenth- and nineteenth-century slavery - serves as the foundation for modernity (288). These slaves endured not just physical trauma but also psychological domination, terror, and pain. And what happens when multicultural communities cause divergent ideas to intersect or position one culture's knowledge as dominant over another's? Zone One investigates the multiple

${ }^{1}$ In Tell My Horse, her second book of anthropology, Hurston photographs a zombie and participates in voodoo rituals. 
traumas of modern life in the quintessential, multi-racial American city, New York, and the ways in which ethnic outsiders use humour and contemporary media to relay their experiences. Whitehead's New York encompasses the "eponymous sitcoms of Jewish comedians; the pay-cable Dominican gangster shows; the rat-a-tat verses of totemic hip-hop singles" (Whitehead 26), the very core of New York City culture. Zone One is an Afrofuturistic novel cynical in its argument that one function of modernity is domination and control, but transgressive in its suggestion that diversity can also be powerful.

Zone One revisits familiar terrain - the Zombie novel - and revitalizes the genre by emphasizing how, traditionally, zombies have represented our fear of the unfamiliar and the unknown, even as that fear imbues our lives with a sense of meaning. Whitehead's novel is actually an amalgamation of surrealist and futuristic elements: its dark humor is characteristic of the Afro-Surreal, but its portrayal of a gloomy, regressive future recalls the dystopian vision of other futuristic science fiction novels. For example, in one of the funniest allusions to New York City's unique character, Mark Spitz, Whitehead's protagonist, notes the zombies' aimless stampede over Central Park, their "moving first this way and then strolling in another direction until . . . they readjusted their idiot course," and remarks of the park, "My God, it's been taken over by tourists" (92). Yet, juxtaposed against this humor is an Afrofuturist critique of technology's capacity for destruction. Mark Spitz is a black man who, as a member of a zombie--fighting team, wields power and control over technology and his life, but, throughout the novel, we see the misery of powerless 
people who have been victimized by technology, mainly that which produced the zombies.

Both Afrofuturism and Afro-Surrealism provide alternate portraits of blackness and address the psychological pressures of modern life, but how (and why), specifically, are these stories being told? The technology of an era has always pervaded modern storytelling, both dictating the stories we tell and revising the ways that we tell them. The prominence of visual technologies (i.e., film, television, video games, and online photographs) means that now novels and cinematic images are in constant conversation. Our modern brains are more accustomed to film techniques than ever before; we think in what pioneering filmmaker Sergei Eisenstein once termed "film language" (108). These film techniques dominate written texts, and, in Afrofuturistic and contemporary Afro-Surreal novels, we see sentences, scenes, and sometimes entire chapters written as montages and jump cuts. The protagonists of these novels often view themselves cinematically, as characters within a film. While this discussion focuses on texts written by African-American authors, the concept applies to any postmodern novel - or to any writers who are hyper-aware of how temporality affects our thinking. In the introduction to the anthology The Secret History of Science Fiction, editors James Patrick Kelly and John Kessel suggest that science fiction writing has grown more present-centered as the modern world becomes more fantastic - from Smartphones that place a universe of knowledge in our hands to ventures into space - and futuristic (1516). 
In Zone One, film swallows the novel: visual technology lives and breathes as one of the characters, and the novel's protagonist views himself as a character from a film. As Whitehead weaves cinematic references throughout his written text, it becomes almost impossible to read Zone One without recalling Night of the Living Dead or The Walking Dead, the comic-book-turned-television-series. In other words, as readers, we experience Whitehead's novel as cinema. Height, for example, a dominant theme throughout all of Whitehead's work, becomes Zone One's most entrenched metaphor for the risks and thrills of progress. For Whitehead, the skyscraper, those enormous buildings that "humiliated runts through verticality" (5), represents how we seek the new and unexplored even as we experience a metaphorical fear of heights and recognize the dangers associated with our ambition. And, ironically, New York City's humanmade skyscrapers and skyline only remind Mark Spitz of his smallness and ineptitude: in an image that recalls Fritz Lang's futuristic film Metropolis, Spitz sees himself as "a mote cycling in the wheels of a giant clock . . . tumbling through its teeth" (5). Through multiple other references to sci-fi and fantasy television and film, Whitehead develops the idea that ostentatious displays of progress only increase our awareness of all that we fail to achieve. And, from the "monster movies on TV" to "the women in monster movies bolting through the woods," to the "ones still standing at the credit roll" (5), Whitehead's highly visual novel is haunted as much by the vestiges of modern life as the zombies themselves. 
Spitz does not long for a reunion with an on-screen image: he is the on-screen image. We learn how Spitz's name originates in seventeen dazzling pages of smash cuts. When a zombie cleanup colleague asks, "Why do they call you Mark Spitz?" (166), Spitz's answer occurs through a series of cuts and flashbacks. Whitehead, as filmmaker/novelist, cuts back and forth from flashbacks to Happy Acres (the relief camp), to present-tense narrative overlaid with Spitz's own voice-over. Whitehead's technique, which is already postmodern, becomes more so as even the voice-over relies on cinematic references to reveal Mark Spitz's identity. We learn he is someone who, like all of us, watches "disaster flicks and horror movies" and believes "he'd survive the particular death scenario," become "the only cast member to heed the words of the bedraggled prophet in Act I" (165-66). Spitz views himself as film character, "as the one left to explain it all to the skeptical world after the end credits," even as he recognizes that real life brings its own surreal horrors: "the real movie started after the first one ended, in the impossible return to things before" (166).

Whitehead's novel is grim, and our final image is of Spitz "walk[ing] into the sea of the dead" (322). Though we don't see Spitz die, we are left questioning his chances for survival, wondering if he can, in fact, overcome the alienation of modern life. Spitz, himself, doesn't "like his chances of making it to the terminal," but, earlier in the novel, Whitehead positions Spitz in an equally impossible situation, but he survives because "[h]e could not die" in a world where one's will is all that matters (182). When the camera is on 
Spitz and the zombies, the metaphor for his fears and insecurities, he cannot help but to survive: "He had the ammo. He took them all down" (183).

Film scholar Laura Mulvey reminds us of scopophilia, the pleasure of watching, the psychological process in which viewers identify with a film's protagonist while, at the same time, mentally separating themselves from a larger, more glamorous projection of the self. Throughout Zone One, we read about - and come to understand - a character experiencing scopophilia, and the more we identify with the character, the more we are implicated in his pain and struggles. As readers, we engage in scopophilia just as Spitz does; Whitehead's highly visual novel forces us to imagine his body, to gaze lovingly upon it and see it reflected in our minds. Mark Spitz and the reader thus share the same tragic flaw: we are unable to separate Spitz's true self from the cinematic and larger-than-life image he holds of himself. Mark Spitz, like many of us, views himself as the hero of his own science fiction fantasy and demonstrates how advanced cinematic storytelling is a form of virtual reality. Afrofuturism thus provides a cautionary tale about the possibilities and limitations of futuristic visual technologies, while Afro-Surrealism, its aesthetic cousin, demonstrates how cinema, a contemporary technology, can be used to highlight historical traumas. 0

\section{Works Cited}

Dery, Mark. Flame Wars: The Discourse of Cyberculture. Durham, NC: Duke UP, 1994. Print. 
Díaz, Junot. The Brief Wondrous Life of Oscar Wao. New York:

Riverhead, 2007. Print.

Eisenstein, Sergei. Film Forum: Essays in Film Theory. Ed. Jay Leyda.

Orlando: Harcourt Brace, 1977.

Eshun, Kodwo. "Further Considerations in Afro-Futurism." The New

Centennial Review 3.2 (2003): 287-302. Web.

Kelly, James Patrick, and John Kessel, eds. The Secret History of

Science Fiction. San Francisco: Tachyon, 2009. Print.

Lavender, Isiah. Race in American Science Fiction. Bloomington:

Indiana UP, 2011. Print.

Mulvey, Laura. "Visual Pleasure and Narrative Cinema." Visual and

Other Pleasures. London: Palgrave Macmillan, 1989. Print. 14-26. Reynaud, Bérénice. "Agnès Varda, Cine-Writer." Walker Dialogue and Retrospective Series. Walker Art, Feb. 2001. Web.

Todorov, Tzvetan. The Fantastic: A Structural Approach to a Literary

Genre. Ithaca: Cornell UP, 1975.

Womack, Ytasha. Afrofuturism. Chicago: Lawrence Hill, 2013. Print. Whitehead, Colson. Zone One. New York: Random House, 2011.

Rochelle Spencer is the co-editor of All About Skin: Short Fiction by Women of Color (University of Wisconsin Press, 2015), and her work appears or is forthcoming in Poets and Writers, Callaloo, East Bay Review, Women's Review of Books, LA Review, Crab Creek Review, Mosaic, Ascentos Review, African American Review, and other journals. A Pushcart Prize nominee, she is the current writer-in-residence at the African American Museum and Library of Oakland, a program spearheaded by Museum Project Coordinator Ms. Veda Silva. 
Afro-Surreal and Afrofuturistic Cinematic Storytelling Pivot 5.1

Return to contents (LINK) 